changes in the nomenclature relating to families and genera. The author of the publication remarks that he has adhered strictly to the "International Rules of Zoological Nomenclature," adopted by the International Congress of Zoology. It seems a pity these adopted rules have been followed by the frequent discoveries that names familiar for the past quarter of a century and more, can no longer be permitted to stand. These neverending changes and the constant growth of the list of synonyms bring about perplexing conditions, even to the technical worker. Some remedy might result, by accepting as a standard, a monumental world's work like Boulenger's "Catalogue of Reptiles of the British Museum." Time would, of course, elicit modifications, but with a standard agreed upon our technical workers would find more time for investigations along more original and generally valuable lines.

Raymond L. Ditmars

NEW York Zoological Park

\section{A REMARKABLE JOURNEY ACROSS THE SAHARA}

ONE of the most daring journeys conceivable on the Sahara has recently been successfully accomplished by Count Réné le More who, almost alone, went from southern Algeria directly across the desert to Timbuctu. The journey of about 8,000 kilometers altogether, to Timbuctu and return, occupied about 13 months, of which three were passed in Timbuctu.

Leaving Ghardaia in November, 1910, le More reached Timbuctu in the last of April. He returned by nearly the same route. Discarding all precedents in Saharan travel, le More was accompanied by only two persons, a servant and an interpreter-guide, both of whom were Arabs. $\mathrm{He}$ had one Touareg riding camel and two small Algerian baggage camels, and carried the minimum amount of baggage, of which two or three American guns formed a prominent and a useful part.

No account of this journey has yet appeared, but in Le Matin, January 15, 1912, there is an interview giving some of the main facts. The route taken in going was by Ghardaia, el Golea, In Salah, Tamanrauet, Kidal to Gan Gao, on the Niger River, thence by the river to Timbuctu. On the return a slightly different course was taken, passing somewhat to the west of Timanrauet, but retracing the previous way from In Salah.

The entire journey was perilous, not only because of the natural dangers attending desert travel, but especially on account of hostile tribes. Soon after le More left Ghardaia, I was told by an officer that the venturesome Frenchman would hardly be able to pass through the Touareg country with so small a company, the Touaregs would surely cut off his head. On the way le More went 29 days, going south from Timanrauet, without seeing any person outside of his own caravan. On the return the little company had exciting adventures in fighting off bands of robbers, coming off with better luck than other travelers through the region. Graves of several unfortunates were seen between Kidal and Gan Gao.

The purpose of the intrepid traveler was to study the country that he might later cross to Timbuctu by aeroplane. As a result he knows the best, or the only situation for relay stations, and much of the conditions attending desert travel, and he considers the project as possible of accomplishment. The result is that le More proposes to cross the desert again, but the next time in the air. Whether this difficult task is finally accomplished by le More remains to be seen, but there is little doubt that in the very near future aeroplanes will not be unknown in the extreme southern part of Algeria, since it is said that the French army in the colony has been actively engaged for several months in working out the details of an aeroplane corps with headquarters at Biskra.

Owing in large part to its relatively high elevation above the sea, the western Sahara is not so intensely arid as the eastern Sahara. In the vicinity of Ouargla and Ghardaia, for example, there is considerable vegetation, especially along the oueds. Le More's photo- 
graphs show, also, that much further south, at In Salah and beyond, over half way to Timbuctu, there is a similar condition of affairs. It is probable, however, that the vegetation of the mesa-like areas, the reg or the hamada, may be barren in the extreme south, since even at Ghardaia there is very little vegetation on such areas. The mid-Saharan country is of the greatest interest botanically since there the Mediterranean element is almost wholly lacking, and the influence of the countries to the south of the desert begins to be felt. We shall await with much expectancy the promised detailed account of this remarkable journey.

Desert Laboratory

\section{W. A. Cannon}

\section{BOTANICAL NOTES}

SUPPLEMENT TO ENGLER AND PRANTL'S ALGAE

The volume of the "Pflanzenfamilien" containing the Algae (I., abt. 2) was completed fourteen years ago (1897), while most of the parts of which it was composed appeared several years earlier. In 1909 two supplementary Lieferungen were issued by Wille, in 1910 two more were issued by Wille, Kjellman and Svedelius, while two more were issued in 1911 by Svedelius. These have now been brought together by the Leipzig publisher, Wilhelm Engelmann, under the subtitle of "Nachtraege zum I Teil, 2, Abteilung." It covers the period from 1890 to 1910, and so brings the treatment of the Algae down to date.

The first thing one notices is the considerable modification of the schematic chart of the relationship of the families of the green algae. The five groups (classes) are developed from the Flagellata, the Protococcales being the primitive class with Volvocaceae as the lowest family. From the latter came the Conjugatae as a side line ending blindly. Above Volvocaceae are placed Tetrasporaceae which lead by one line through Protococcaceae to Hydrogastraceae and Valoniaceae, and by the other to Ulvaceae. The family Valoniaceae is regarded as the lowest of the class
Siphonocladales, which culminates in Dasycladaceae and Sphaeropleaceae. From Valoniaceae a line reaches Bryopsidaceae in Siphonales, culminating in Vaucheriaceae. The Ulvaceae are the lowest of the Chaetophorales, which pass by several lines to Chroolepidiaceae, Coleochaetaceae and Oedogoniaceae at the summits of as many genetic lines. A significant thing in the treatment of these families of green algae is the association of five families of colorless plants as "Nebenformen" related to Volvocaceae, Pleurococcaceae, Protococcaceae, Oocystaceae, and Oedogoniaceae, thus adding another step to the movement for the obliteration of the distinction between algae and fungi, and their assembling into new groups on morphological characters.

In passing it may be noted that Pleurococcaceae are separated from Protococcaceae by the absence of zoospores in the former and their presence in the latter, contrary to some recent algologists. Nor has the author been stampeded into dividing Hydrogastraceae and in his system Protosiphon and Botrydium lie peacefully side by side as related genera in the same family. Characeae are still so placed as to immediately follow Siphonales, and by this one is reminded of Wille's suggestion of their relationship in his earlier treatment. The revision of the Phaeophyceae was partly made by Kjellman, and on his death it was continued by Svedelius. It thus happens that some of the families are the joint work of the two authors, while in other cases Svedelius alone did all of the work, as in Sphacelariaceae, Laminariaceae and Fucaceae. The revision of the Rhodophyceae also is the work of Svedelius. Here the treatment is necessarily the same as that of Schmitz and Hauptfleisch fourteen to fifteen years earlier. However in the difficult family of the Corallinaceae the genera of the earlier treatment are freely broken up into smaller ones in accordance with the trend of recent opinion, resulting in the recognition of twenty-four genera instead of nine, with a considerable shifting of their places in the family. 